\title{
Biochemical Studies on Carbohydrates.
}

\author{
CXV. Hexosamine Compounds in Lung.
}

Fourth Report: Glycidamins as a Component of Nucleoproteins.

By

\section{Motoyuki Utusi.}

(宇津志元亭)

(From the Medico-Chemical Institute, Tohoku University, Sendai. Director: Prof. H. Masamune.)

(Received for publication, November 11, 1947)

Since Steudel it is generally believed that nucleoproteins are salts of a nucleic acid with a basic protein. But of those separated from various sources, many are obscure regarding the nature of the involved protein and do not contain nitrogen more than 16\%. The examples are those from spleen, bone-marrow, hepatopancreas of octopus, submaxillary gland, placenta, brain and blood serum." The proteins in these nucleoproteins are most probably the acidic, when analogized from the case of glycoproteins in the sense of Masamune." We $\mathrm{We}^{3 /-6)}$ have found that "glycoproteins" separate out, when tissue extracts are acidified, by combination of an acid protein with a hexuronic acid-containing polysaccharide through the ionized basic radicles of the former and the acidic of the latter. Acid proteins are suspected to participate also in making up nucleoproteins by a similar mechanism. Since, among acid tissue proteins, glycidamins are most readily extractible because of their having a carbohydrate in their molecule, these particularly might have opportunities to contribute to the production of nucleoproteins, and as a matter of fact, we were often perplexed to eliminate the accompanying nucleic acid, when isolation of pure glycidamins was aimed at as in studies of sclera mucoids", the mucin of stomach mucosa ${ }^{81}$ and others.

The present experiment was so schemed in order to endorse the above supposition by taking advantage of the glacial acetic acid-soluble fraction (B fraction in the first report ${ }^{9}$ ) of a lung extract. Its solution in dilute methanol was precipitatdd by acidulation. In the precipitate were present both the nucleic acid and group specific glycidamin. On the other hand, the free nucleic acid was isolated by means of $\mathrm{Ba}(\mathrm{OH})_{2}$ from the same material. Analysis of these substances showed that $3 / 4$ part of the nucleoprotein here was occupied by the glycidamin. 


\section{EXPERIMENTAL.}

The Nucleic Acid.

$300 \mathrm{mgms}$. lots of a $\mathrm{B}$ fraction of lung were dissolved in $8 \mathrm{cc}$. of water ${ }^{10)}$ and drop by drop of the saturated $\mathrm{Ba}(\mathrm{OH})_{2}$ was added. The precipitate occurring at neutral reaction was discarded and that at $\mathrm{pH} 9.4$ was collected. The latter was suspended in $10 \mathrm{cc}$. of water and dissolved by acidifying with $3 \% \mathrm{HCl}$ till $\mathrm{pH} 3.4$, then the insoluble part centrifuged off and the supernatant liquid neutralized with $2 \% \mathrm{NaOH}$. Deposits appeared again. From the clear centrifuged supernatant fluid was the nucleic acid recovered by precipitation similar to above. It was washed with $95 \%$ alcohol and with ether and dried (in vacuo over $\mathrm{CaCl}_{2}$ ). Crop, $76 \mathrm{mgms}$.

In this barium salt was shown the presence of phosphorus (ammonium molybdate test), sugar (Molisch reagents gave a bloodred colour tinged with violet), pentose (aniline acetate test) and purine bases (ammoniacal $\mathrm{AgNO}_{3}$ test), but the substance did not give biuret and hexosamine (Osaki and Turumi procedure) reactions. Quantitatively, it contained $13.60 \% \mathrm{~N}$ (micro Kjeldahl), $6.68 \% \mathrm{P}$ (Plimmer ${ }^{11}$ ) and $14.60 \%$ ash. In order to measure the optical rotatory power, the substance was dissolved in water by the use of hydrochloric acid. The $\mathrm{pH}$ of the solution was 5.6. $[\alpha]_{\mathrm{D}}^{4}=\frac{1.10 \times 3.0125}{0.0181 \times 1.0024 \times 1}=+182.6^{\circ}$.

When it is assumed that the phosphate rests of the present nucleic acid possess each only one non-chemically-bound $\mathrm{OH}$ as in thymo- or yeastnucleic acid and are combined fully with $\mathrm{Ba}$ in the salt, the composition of the acid in free state is calculated at: $\mathrm{N}, 15.91 \% ; \mathrm{P}, 7.82 \%$.

The Nucleoprotein.

600 mgms. from the material used above were purified by redissolution in glacial acetic acid (extracted with a $5 \mathrm{cc}$. and a $3 \mathrm{cc}$. portion of the solvent) and reprecipitation of the clear centrifuged supernatant fluid with acetone. After washing with acetone and ether and drying, the amount recovered was $400 \mathrm{mgms}$. This was taken up in $10 \mathrm{cc}$. of water ${ }^{12}$ and $5 \mathrm{cc}$. of $97 \%$ methanol (More of methanol caused precipitation) and subsequently $30 \%$ acetic acid were added. The precipitate, which came out at $\mathrm{pH} 4.5$, was centrifuged, washed with acid dilute methanol (similar to the mother liquid as to dilution and $\mathrm{pH}$ ), then with $95 \%$ alcohol and ether and dried.

Two specimens were thus prepared. About $250 \mathrm{mgms}$. were yielded in each case.

Tests. Biuret, Molisch, Osaki and Turumi (by both the direct and indirect processes), ammonium molybdate (for phosphorus), ammoniacal 
$\mathrm{AgNO}_{3}$ and aniline acetate tests resulted in positive.

Analysis gave results in Table I.

TABLE I.

Composition of the Nucleoprotein.

Figures express the percentages.

\begin{tabular}{l|r|r|r}
\hline \multicolumn{1}{c|}{ Analysis } & Sp. I & Spe. II & Average \\
\hline $\mathrm{N}$ & 13.18 & 13.25 & 13.22 \\
Glucosamine & 10.55 & 10.38 & 10.47 \\
$\mathrm{P}$ & 2.10 & 1.93 & 2.02
\end{tabular}

Computed separately from the content of phosphorus and of glucosamine (the group-specific glycidamin contains $13.99 \%$ glucosamine $\left.{ }^{13}\right)$, it is given that $1 / 4(26 \%)$ of this nucleoprotein is taken up by the nucleic acid and $3 / 4(75 \%)$ by the glycidamin. Nitrogen of the nucleoprotein is calculated from this proportion at $13.5 \%$ (nitrogen of the glycidamin, 12.72\%), coinciding nearly with the values found.

We are indebted to the Grant Committee for Scientific Researches of the Education Department for a grant to us. H, M.

\section{Bibliography and Notes.}

1) Readers are referred to Steudel (Hoppe-Seyler and Thierfelder, Handb. d. physiol. u. path.-chem. Analyse, 9th Ed., Julius Springer, Berlin, 1924, 533-541).

2) Masamune, Tohoku J. Exp. Med., 1949, 50, 107.

3) Hasegawa, ibid., 1943, 46, 95.

4) Oh-Uti, T., ibid., 1948, 49, 193 and 207.

5) Asagi, ibid., 1949, 50, 95.

6) Masamune and Yasuoka, ibid., 1947, 49, 181.

7) Osaki, ibid., 1947, 49, 19.

8) Ozaki, J. Bioch., 1937, 26, 239; Sibuya, Tohoku J. Exp. Med., 1949, 50, 355.

9) Utusi, Tohoku J. Exp. Med., this volume, p. 101.

10) A clear solution was obtained.

11) Cf. Haneda, Sinokawa and Yasuoka, Tohoku J. Exp. Med., 1944, 46, 263.

12). The substance dissolved perfectly.

13) See the second report (Tohoku J. Exp. Med., this volume, p. 175). 